\title{
ERRATUM
}

\section{Erratum to: Folded plate structures made of glass laminates: a proposal for the structural assessment}

\author{
Stefan Marinitsch • Christian Schranz • \\ Martien Teich
}

Published online: 26 January 2016

(C) Springer International Publishing Switzerland 2016

\section{Erratum to: Glass Struct Eng DOI 10.1007/s40940-015-0002-1}

With regard to Table 6 , the superscript 4 should be removed from all occurrences of $(\mathrm{kN} / \mathrm{m} 4)$.

The online version of the original article can be found under doi:10.1007/s40940-015-0002-1.

S. Marinitsch $(\varangle) \cdot$ C. Schranz $\cdot$ M. Teich

Vienna, Austria

e-mail: stefan.marinitsch@seele.com

C. Schranz

e-mail: Christian.schranz@tuwien.ac.at

M. Teich

e-mail: Martien.teich@seele.com 